Received: 04/08/2018

\title{
Enhancing Different Ethnicity Science Process Skills: Problem-Based Learning through Practicum and Authentic Assessment
}

\author{
Hilarius Jago Duda \\ Biology Education Study Program, STKIP Persada Kathulistiwa Sintang, West \\ Kalimantan, Indonesia, hilariusjagod@yahoo.com

\section{Herawati Susilo} \\ Biology Department, Graduate Studies of State University of Malang, Indonesia, \\ herawati_susilo@yahoo.com
}

\section{Peter Newcombe}

The University of Queensland Brisbane, Australia, newc@psy.uq.edu.au

\begin{abstract}
Problem-Based Learning (PBL) is a constructivist learning with the potential to enhance students' science process skill. The implementation of PBL has revealed many advantages; however, a free exploration from a highly complex environment may result in a heavier workload of memory. Accordingly, practicum method can be used to overcome the shortcomings of PBL with the support of authentic assessment. This research aimsed to investigate the effect of PBL through practicum supported by authentic assessment, PBL, and conventional learning on science process skills of Dayak and Malay students in Animal Physiology lectures. The research used a quasi-experimental research design with a pretest-posttest nonequivalent control group design with $3 \times 2$ factorial design. Data collection involved a science process skill test. The data were analyzed descriptively and inferentially with ANCOVA. Significant differences between groups were assessed with LSD test. The result showed that the learning model influenced students' science process skill. The PBL model implemented through a practicum and supported with authentic assessment was the most influential being significantly different to both PBM model and conventional learning. Ethnicity did not significantly affect the students' science process skill. There was no interaction between learning model and ethnicity toward students' science process skill.
\end{abstract}

Keywords: problem based learning, practicum method, authentic assessment, ethnicity, science process skill, Indonesia

Citation: Duda, H. J., Susilo, H. \& Newcombe, P. (2019). Enhancing Different Ethnicity Science Process Skills: Problem-Based Learning through Practicum and Authentic Assessment. International Journal of Instruction, 12(1), 1207-1222. https://doi.org/10.29333/iji.2019.12177a 


\section{INTRODUCTION}

One of the factors that can influence the learning process is ethnicity, which is a demographic factor with a socio-cultural environment. The result of a survey conducted from June to July in 2013 showed that the most dominant ethnic group in Biology Study Program of STKIP Persada Khatulistiwa Sintang Indonesia were Dayak and Malay students. The former is a local Indigenous ethnicity, and the latter are immigrants, who have been living in Kalimantan for a long period of time. Inter-ethnic conflicts have occurred in West Kalimantan, especially in the Sambas and Landak Districts. The conflicts usually occurred in dominant ethnic groups, such as Dayak and Malay, due to economic factors. It is widely known that the economy is strongly influenced by education. For example, Saripudin (2008) found a steady and positive relationship between the degree of education and economic life, in which the higher the education degree, the higher the economic life quality. Investment in education will significantly stimulate economic progress and create social welfare. Thus, researchers are interested in ethnic factors in learning as an effort to prevent economic conflicts that may occur in the future.

The results of a survey that was conducted from June to July 2013 in STKIP Persada Khatulistiwa also revealed that ethnicity has not been put into attention during the learning process, despite students in the college having different ethnic backgrounds. The role of education in preventing conflicts is significantly important, as asserted by Azra (2005) who commented that the occurrence of various social conflicts, among others, was due to the lack of understanding and appreciation for other ethnic cultures, and then one of the attempts to resolve such a conflict is to educate people to appreciate various cultural differences in society. The function of education as transfer of values and knowledge explains why education is a significant way forward.

Research has shown that in term of process, an important factor in ethnic education is the learning model used by the teacher to convey the content of ethnic education which is integrated with the learning materials. In relation to the implications of ethnic education for conflict-prone areas in West Kalimantan, the most appropriate learning model would be a model which places greater emphasis on inter-ethnic cooperation, ethnic difference appreciation, as well as value analysis or value internalization (Aswandi, 2010).

Science and science learning not only focus on knowledge and thinking, but also focus on other dimensions, such as the learning process. The skills performed during engagement in science-based activities are called the science process skills. According to Ahmad and Rubba, (in Kurniati, 2001), science process skills are the cognitive skills used by scientists as a systematic approach to problem solving. Thus, science process skills are an main asset for students in studying science which can support the mastery of science concepts. Scientific process skills, such as problem solving and individual as well as social development through mental, physical, and competence ability, are an important and necessary tool in science and technology learning (Akinbobola \& Afolabi, 2010). Scientific process skills are important in helping learners develop the learning process through their experiences. Students should be given the opportunity to develop 
their abilities (Pardhan, 2000).

One of the teaching models to address the previously mentioned problem is the Problem-Based Learning Model (PBL), since the model can facilitate collaboration among students. PBL is an environment of learning, in which issues encourage the occurrence of learning. In addition, PBL is a student-centered method where students can independently build their knowledge. PBL involves many cognitive challenges, as the students are attempt to understand the problem situation, explain the causes of the problem, decide the important facts to be investigated, and generate hypotheses for the solution. PBL is believed to be effective in improving social skills through group work (Albion, 1999; Duch, Groh \& Allen, 2001). PBL also facilitates students learning through real-life solutions, authentic problems, and inter-discipline knowledge integration. PBL places emphasis on skills and behaviors and within a group (Aspy et al, 1993; Koh et al, 2008 in Achuonye, 2010).

According to Tan (2009), PBL's emphasis is on enhancing and improving the way of learning with the aim of strengthening concepts in real situations, developing problemsolving skills, improving students' learning activities, developing decision-making skills, gathering information, and also increasing confidence, responsibility, cooperation, as well as communication. Sungur et al. (2006) found that teaching and learning activities which implement the PBL model supported students to be better at using, integrating, and interpreting relevant information by proposing solutions more than did those in control class which implemented traditional methods. Kirschner, Sweller, and Clark (2006) suggests that although the benefits of PBL can help students to gain meaning from the subject matter, the cognitive load theory suggests that free exploration of highly complex environments can result in heavier workloads of memory that can be harmful for learners. Accordingly, the present research is interested in integrating PBL with practicum method, so that problem solving can be more focused through the practicum to relieve cognitive burden on students.

Practicum method is known to enable students to learn a concept directly through observations and experiments, thereby improving student skills. One of the learning approaches that is in line with the nature of constructivism is practicum-based learning. In practicum-based learning, the learning activities are directed to experimental learning based on concrete experiences and discussions with friends in order to acquire new ideas and concepts. Learning is seen as a process of composing knowledge from concrete experiences, collaborative activities, reflections and interpretations. According Hartono \& Rustaman (2010), the science process skills can be applied in laboratory activities directly and or virtually. This is supported by Salomon (in Duda 2010) who argued that through practicum activities, teachers aim for children to be more understand of the concepts being learned. Moreover, it also helps in enhancing students' motivation to learn science, developing students' scientific skills, as well as growing their scientific attitude. For students, the implementation of practicum learning can also help them to enjoy new experiences to observe, to try, to use tools, and to do experiments. Therefore, practicum activities in biology learning are important.

Santyasa (2004) explained that practice-based learning is a good learning strategy for 
students to develop skills as they are required to be active in solving problems, in analyzing and applying facts, as well as in finding concepts and principles in order to become more meaningful. Halimatul and Supriyanti (2006) suggested that practicum activity is a vehicle of learning that can be used to train and develop skills. Duda (2010) revealed that the weakness of the practicum method was that the laboratory was not associated with authentic problems in the environment, so students might only understand theoretical problems and not understand the application that occurs in the field. Therefore, researchers need to integrate the practicum into a problem-based learning model. In addition, researchers also need to provide authentic tasks in problembased learning models through practicum in order to motivate students to be active in the learning process, thus optimizing the learning process.

There are several authentic tasks that can be assigned to students, including creating daily journals, practicum reports, portfolios, and presenting group performances that involve formal observations of peer information or peer assessment. That is, it incorporates a performance assessment during the learning process by peers, and information by the lecturers or assessment of the learning process from the beginning to the end of the learning. According to Hart (1994), authentic assessment is assessment based on students' presentation or performance in the form of assignments or certain activities that directly have educational meaning. For Wiggins (1989), authentic assessment acts as an opportunity for instruction and skill formation, not merely as evaluation tool. Authentic assessment can support classroom instruction, gather evidence from multiple activities, generate inter-participant teaching and learning, and reflect local values, and standards (Frey et al., 2012). The present research aimed to investigate the effect of problem-based learning through practicum, which is supported with authentic assessment, as well as the effect of ethnicity on students' science process skill.

\section{METHOD}

\section{Research design}

The study is a quasi-experimental research aimed to determine the implementation effect of three learning models on students' science process skills. The research design used was a nonequivalent pretest-posttest-control group design with 3 (Learning Models) x 2 (Ethnic Group) factorial pattern. The three levels of Learning Models included: 1) Problem-Based Learning (PBL), 2) Problem-Based Learning through practicum, which is supported by authentic assessment, and 3) conventional learning. The moderator variable or the secondary independent variable consists of 2 levels, namely Dayak and Malay ethnics. The dependent variable is student science process skill. There are 2 control variables, i.e. manually and statistically. The former refers to the same time, lecture materials, and the lecturer; meanwhile the latter refers to the pretest. The research design used can be seen in Figure 1. 


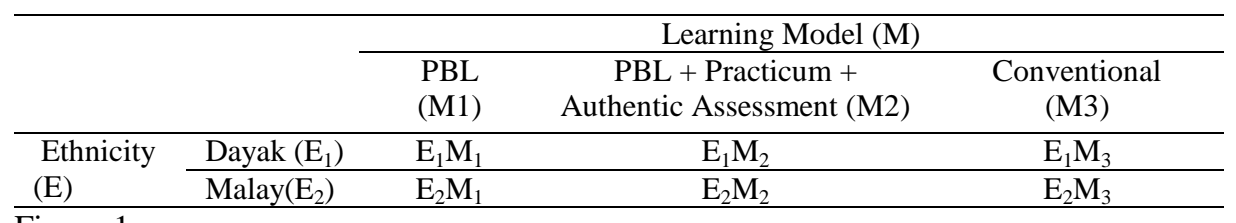

Figure 1

Nonequivalent Pretest Posttest Control Group Design with factorial Pattern of $3 \times 2$ (Source: Ary, et al., 1982: 365)

Information:

$E_{1} M_{1}$ : Dayak ethnic group who was treated with problem-based learning model through practicum supported by authentic assessment

$\mathrm{E}_{2} \mathrm{M}_{1}$ : Malay ethnic groups who was treated with problem-based learning models through practicum supported by authentic assessment

$\mathrm{E}_{1} \mathrm{M}_{2}$ : Dayak ethnic group who was treated with PBL model

$\mathrm{E}_{2} \mathrm{M}_{2}$ : Malay ethnic group who was treated with PBL model

$\mathrm{E}_{1} \mathrm{M}_{3}$ : Dayak ethnic groups who was treated with conventional learning

$\mathrm{E}_{2} \mathrm{M}_{3}$ : Malay ethnic group who was treated with conventional learning

\section{Population and Sample Research}

The research population was all students of Biology Education Study Program at STKIP Persada Khatulistiwa Sintang West Kalimantan, Indonesia, in 2013/2014 academic year. The population consisted of 500 active students who were within their first eight semesters in Biology Education Study Program. Student age ranges from 19 to 22 years. The sample chosen in this study were students who were studying in the even semester and enrolled in Animal Physiology. Purposive sampling was used to recruit participants. The selected sample was three classes with 60 students in each class, 180 participants in total. Accordingly, this study used three classes for three types of instructional model, namely (1) conventional learning model, (2) problem-based learning model, and (3) problem-based learning model through practicum supported with authentic assessment.

\section{Research Instruments}

The outcome measure was a student science process skill test. The first step in the development of science process skill test questions was to create the test content outline based on the lesson indicators, the science process skills indicators, the assessment aspect, and the number of questions. The subsequent step is the writing of the test item. The type of test used in this study was a written test in the form of an essay test. In addition to the test item, it is also provided with an answer key and assessment rubric. The outline of the science process skill test included the number, sub concepts, types of science process skill, science process skill indicators, item number, and score. The total of the developed science process skill test items are 24 question items. Rubric tests of science process skills have a range of values from $0-4$, where the highest score is 4 , and the lowest score is 0 . Before the research instrument was used, it was examined for validity, reliability, item difficulty, and item discriminating power using anates program. 
The developed science process skills test was aimed to assess students' psychomotor learning achievements on animal physiology materials before and after the learning.

\section{Data analysis technique}

Data analysis techniques involved both descriptive and inferential statistics. The descriptive statistics included mean, standard deviation, highest average, lowest average, and percentage of pre-test and post-test change. The inferential statistics through ANCOVA was conducted to test the proposed hypothesis. Prior to the ANCOVA, prerequisite tests in the form of normality and homogeneity test were conducted. Follow-up tests of significance of the difference in variable mean value used LSD test. The statistical calculation was conducted with SPSS V21 with a significance level of alpha $=0.05$ adopted

\section{FINDINGS}

\section{Learning model}

Measurement of students' science process skills was conducted prior to (pre-test) and after (post-test) the teaching and learning process. The descriptive data relating to the focal variables is presented in Table 1. The collected data of students' science process skills were then analyzed by using descriptive statistics to find out the average of the students' science process skills on each independent variables and moderator. The result of descriptive analysis on students' science process skill showed that the average of students' science process skill revealed by the pretest is in less category for all treatments, meanwhile the students' science process skill revealed by the posttest is in the very good category for treatment by using problem-based learning model through practicum which are supported by authentic assessment and good categories for problem-based learning and conventional learning. The profile of students' science process skill is visually presented in Figure 2.

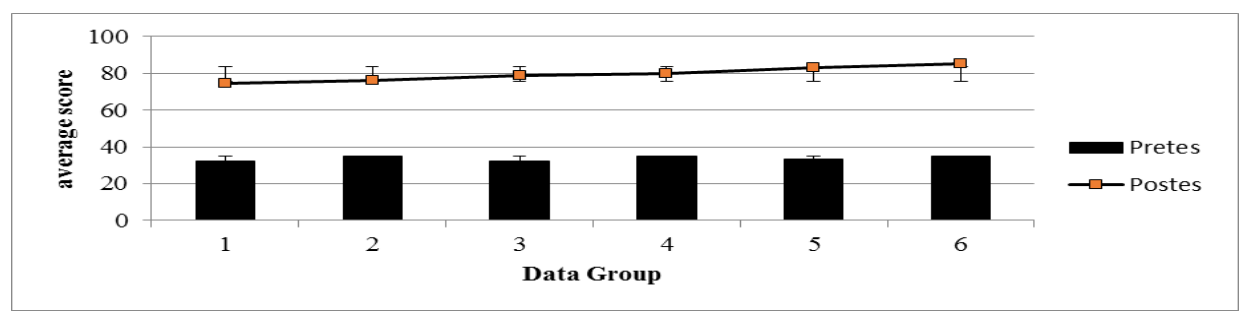

Figure 2

Profile of the Average of Students Science Process Skills Before and After Learning for The Three Treatments

Description:

$1=$ Dayak group on conventional learning

$2=$ Malay group on conventional learning

$3=$ Dayak group on problem-based learning

$4=$ Malay group on problem-based learning 
$5=$ Dayak group on problem-based learning through practicum supported with authentic assessment

$6=$ Malay groups on problem-based learning through practicum supported with authentic assessment

Table 1

Tests of Between-Subjects Effects

\begin{tabular}{llllll}
\hline Dependent Variable: YKPS & Type III Sum of Squares & df & Mean Square & F & Sig. \\
\hline Source & $2925,778^{\text {a }}$ & 6 & 487,630 & 36.313 &, 000 \\
\hline Corrected Model & 3109,448 & 1 & 3109,448 & 231,557 &, 000 \\
\hline Intercept & 544,734 & 1 & 544,734 & 40,566 &, 000 \\
\hline XKPS & 2073,179 & 2 & 1036,589 & 77.194 &, 000 \\
\hline Model &, 244 & 1 &, 244 &, 018 &, 893 \\
\hline Ethnicity & 18,382 & 2 & 9,191 &, 684 &, 506 \\
\hline model * ethnicity & 2323,116 & 173 & 13,428 & & \\
\hline Error & 1145598,500 & 180 & & & \\
\hline Total & 5248,894 & 179 & & & \\
\hline Corrected Total & (Adjusted R Squared $=542)$ & & & & \\
\hline a. R Squared $=, 557$ &
\end{tabular}

The results of covariance analysis listed in Table 1 shows that $\mathrm{F}$ counted of learning model variable is 77.19 with a significance level of 0.00 which is smaller than the alpha 0.05 , thus the $\mathrm{H}_{0}$ is rejected. Accordingly, the research hypothesis, which stated that there is an influence of learning model on students' science process skill is accepted. Thus, the researchers inferred that the application of the learning model influences the students' science process skills. On the basis of covariance analysis results, which indicated a significant influence, then a further analysis can be conducted with the LSD test to determine the average difference of each learning model. LSD test results of students' science process skills for the three models can be seen in Table 2.

Table 2

LSD Test Result on The Average Difference of Student Science Process Skill on Every Treatment

\begin{tabular}{|c|c|c|c|c|c|}
\hline Model & Pretest & Posttest & Difference & Critical Corrected & LSD notation \\
\hline Conventional & 33.63 & 75.30 & 41.68 & 75.47 & $\mathrm{a}$ \\
\hline PBL & 33.83 & 79.46 & 45.63 & 79.49 & b \\
\hline Modified Model & 34.18 & 84.03 & 49.85 & 83.82 & $\mathrm{c}$ \\
\hline
\end{tabular}

The result of LSD test shows that there are significant differences between the three models, in which the problem-based learning model through practicum supported with authentic assessment is significantly different from the problem-based learning model, and the problem-based learning model is also significantly different from the conventional learning model. It is evident from average value of the corrected science process skill in which the highest was found in the problem-based learning model through a practicum supported with authentic assessment with an average corrected science process skill of 83.82 , followed by problem based learning and conventional learning with the average corrected science process skill of 79.49 and 75.47 , 
respectively. From the difference of LSD notation, it can be explained that the average of corrected science process skills in the problem-based model learning group through the practicum supported with authentic assessment is significantly different. It is 4.32 higher than the average corrected science process skills in the problem-based model learning group, and 8.34 higher than the average corrected science process skills in the conventional learning group.

\section{Ethnicity}

The result of covariance analysis in Table 1 shows that $\mathrm{F}$ count of ethnic variable is 0.018 with a significance level of 0.89 , which is greater than the value of alpha 0.05 , thus $\mathrm{H}_{0}$ is accepted. Accordingly, the research hypothesis stated that there is an ethnic influence on students' science process skills is rejected. The results did not show any significant effect on covariance analysis. Thus, the analysis can still be continued by calculating corrected value to know the mean difference in every ethnic. Based on the posttest average score, it is known that the science process skills of Dayak ethnic students is lower than Malay ethnic students. The average value of scientific process skills for both ethnics is presented in Table 3.

Table 3

LSD Test Results on Mean Difference of Students Science Process Skills on Both Ethnicities

\begin{tabular}{lllll}
\hline Ethnicity & Pretest & Posttest & Difference & Critically Corrected \\
\hline Dayak & 32.81 & 78.89 & 46.09 & 79.63 \\
\hline Malay & 34.94 & 80.29 & 45.35 & 79.55 \\
\hline
\end{tabular}

\section{Interaction of Learning and Ethnic Model}

The interaction of learning model and ethnicity can be seen from the covariance analysis result in Table 1, which shows that $F$ count of interaction variable is 0.68 with a significance level of 0.51 , which is much larger than the alpha value of 0.05 as the standard of analysis. Therefore, $\mathrm{H}_{0}$ is accepted and the research hypothesis that there is an interaction effect of learning model and ethnic on the students' science process skills is rejected. The analysis was continued by the LSD test to determine the mean difference at each treatment level, although it did not show any significant effect on the covariance analysis. The result of the LSD test on the average difference at each level of treatment is presented in Table 4.

Table 4

LSD Test Results on Mean Difference of Student Science Process Skills at Each Treatment Level

\begin{tabular}{lllllll}
\hline Model & Ethnicity & Pretest & Posttest & Difference & $\begin{array}{l}\text { Critically } \\
\text { Corrected }\end{array}$ & $\begin{array}{l}\text { LSD } \\
\text { notation }\end{array}$ \\
\hline Conventional & Dayak & 32.217 & 74,667 & 42.450 & 75,814 & $\mathrm{a}$ \\
\cline { 2 - 7 } & Malay & 35,033 & 75,933 & 40,900 & 75.132 & $\mathrm{a}$ \\
\hline \multirow{2}{*}{ PBL } & Dayak & 32,850 & 78.967 & 46,117 & 79,676 & $\mathrm{~b}$ \\
\cline { 2 - 7 } & Malay & 34,800 & 79,950 & 45,150 & 79.310 & $\mathrm{~b}$ \\
\hline \multirow{2}{*}{ Modified Model } & Dayak & 33,350 & 83,050 & 49,700 & 83.413 & $\mathrm{c}$ \\
\cline { 2 - 7 } & Malay & 35,000 & 85,000 & 50,000 & 84,222 & $\mathrm{c}$ \\
\hline
\end{tabular}


The result of LSD test shows that the highest average of students' science process skill was found in the group of problem-based learning model through practicum supported with authentic assessment of Malay ethnic, meanwhile and the lowest average of science process skill was found in conventional learning group of Dayak ethnic. Based on the difference in notation, it can be explained as follows: The corrected average of Malay ethnic students' science process skill who learned with problem-based learning model through a practicum supported by authentic assessment was 4.91 higher and significantly different from the corrected average of the Malay ethnic students' science process skills who learned with problem-based learning model, and 9.09 higher and significantly different from the corrected average of Malay ethnic students' science process skills who learned with conventional learning model.

The corrected average of Malay ethnic students' science process skills on the problembased learning model through a practicum supported by authentic assessment were not significantly different and 0.81 higher from the average science process skills of Dayak ethnic students on the problem-based learning through practicum supported by authentic assessment. The average of the Malay ethnic students' science process skill that learned with problem-based learning model is not significantly different from the average of Dayak ethnic students' science process skills who learned with problem-based learning model. Similarly, the average of Malay ethnic students' science process skills that learned with conventional learning model is not significantly different from the average science process skills of Dayak ethnic students who learned with conventional learning model.

\section{DISCUSSION}

\section{Learning model}

LSD notation information provides support on the assertion that the learning model that can give a significant influence and contribution to the improvement of students' science process skills is the problem-based learning model through a practicum supported by authentic assessment. Descriptively, the level of students' science process skill after the research intervention showed a maximum achievement of science process skill, which is in a very good category. The result of data analysis shows that there is an influence of problem-based learning model through practicum supported by authentic assessment on students' science process skill. The average of students' science process skills in problem-based learning groups through practicum supported by authentic assessment is significantly different from the average of students' science process skills in problembased learning groups and conventional learning groups.

The high score of the students' science process skills is the impact of the components of problem-based learning model through a practicum supported by authentic assessment, namely analyzing problem, conducting practicum, and creating authentic task. The first component is analyzing the problem (recent theory) according to Arvyaty and Saputra (2013) that the problem-based learning model is learning the subject of knowledge in the context of using and developing the science process skills. PBL puts more emphasis on learning, as the syntax encourages students to develop the science process skills 
(Akınoğlu \& Tandoğan, 2007). PBL unites theory and practice, thus it allows students to combine their old knowledge with new knowledge as well as to develop their skills in assessing within a particular discipline (Akınoğlu \& Tandoğan, 2007). Problem-based learning model that is oriented towards learners and empowers investigation activities, integrate the theory and practice, and actively apply knowledge and skills to develop solutions while defining problems (Savery, 2006).

The second component affecting the science process skills is practicum, as suggested by Trowbridge and Bybee (1990) that practicum activities are activities that play a role in developing the science process skills. This is supported by Gabel (in Wulan, 2003) that laboratory or practicum activities can provide opportunities for students to develop their skills. According to Rustaman (2007), The principle of learning is "learning by doing". Thus, it is emphasized that learning will be more meaningful if the students can experience or do the task themselves (not verbalistic). Duda (2017) suggested that learning based on practicum can empower students' science process skills. Villani (1992) explained that students can solve science problems by linking observations or experiments with their theoretical constructs so they can build their concept structures well. Laboratory activities also provide opportunities for students to develop skills (Gabel, 1994). Dahar (2011) asserted "science laboratories play a very important role in the teaching-learning process of science subjects". The results of Jeenthong et al. (2014) found that students in the experimental group who used laboratory showed significantly higher scores of science process skills in the posted compared to students in the control group that use direct instruction. This is because students in the experimental group have the opportunity to create hypotheses, identify variables, design, and execute experiments, as well as to collect data.

A third component which affects the science process skills is the making of authentic tasks, as advocated by Oneil (1992) that authentic assessment provides more complete data about students' abilities and based on learning activities, rewards products (in terms of concepts, procedures, propositions, laws, theories) and processes (in the form of steps in the scientific method) equally well. Authentic assessment is an exciting effort to stimulate learning and make it more relevant (McAlister, 2000). Marhaeni (2008) explained that authentic assessment is highly capable of providing a real picture of the learners' condition, and at the same time providing a direct experience for the learner. According to many experts (Airasian, 1991; Stiggins, 1994; Pophan, 1995; Gronlund, 1998; Zainul, 2001 in Wulan 2007), performance appraisal with feedback encourages the application of learning to real life situations and had been proved to be effective in motivating students. It is supported by Pantiwati (2012) who advocated that authentic assessment is very useful for students as it can direct and develop the skills so that students have more opportunities to demonstrate their competence.

In the second treatment, it can be seen that there is an effect of problem-based learning model on science process skill. The average score of science process skills of students who learned with problem-based learning model is higher than the average science process skill score of students who learned with conventional learning. The high scores of students' science process skills are the implications of the implementation of problem- 
based learning models. Problem-based learning model is a science learning that emphasizes learning on authentic problem and problem solving. During the learning process, students study in groups, in which each student will read the problem and will then solve the problem by reading a book in the classroom, visiting the library, visiting the internet as well as the surrounding environment (Arends, 2008). By doing some activities to solve the problem, it is expected that students' science process skill will be improved.

Based on the learning stages, it can be seen that the component that affects the students' science process skills is the solving of problems. According to Kwan (2000), problembased learning encourages the thinking and active integration of information and has improved research skills. In addition, problem-oriented problem-based learning also helps to strengthen learner's knowledge of the basic science and its relevance. PBL is a learning approach that offers the potential to help students develop a flexible understanding and lifelong learning skills (Hmelo-Silver, 2004). PBL strategy will explore complex skills with a set of complex mental components, cognition, metacognition, non-cognitive variable, and justification skills (Jonassen, 1997).

\section{Ethnicity}

The result of the analysis shows that the average of science process skills in the Malay ethnic group is higher than the average of science process skill in Dayak ethnic group, although it is not significantly different. The corrected averages indicate that there is an increase in teaching and learning process in both Malay and Dayak ethnics. Similarly, descriptive statistics analysis also showed the increasing level of students' science process skills after receiving treatment, which reflects the optimal success of the science process skills as excellent categories can be achieved.

From the data, it can be seen that in problem-based learning, either the Malay or Dayak group have achieved the value of science process skill, which is not much different. This is due to the characteristics of the two ethnic cultures, as expressed by Purpleitadyah (2012) that Dayak people are always characterized by living together that is reflected by their long house, although such houses are increasingly disappearing. In addition, Dayaks always cooperate in opening fields or gardens, possessing rich natural and cultural resources. Therefore, their characteristics are appropriate with the problembased learning model, which requires cooperation in solving problems.

In addition, another reason that causes Dayak education and knowledge to increase is because many Dayak tribes have studied with other tribes such as Java, Batak, Timor, China, and others due to marriage or other reasons. It is explained by Purpleitadyah (2012) that not all Dayak people have a pure Dayak blood, since many of them have mixed with other ethnicity due to marriage or other reasons. In addition, since the Dayak always work with the natural environment, such as forests, fields, rivers, etcetera, where living creatures both plants and animals can be found, they tend to love learning about living things, such as the concept taught in the study, i.e. animal physiology. 


\section{Interaction of Learning Model and Ethnic}

The results of anacova analysis show that there is no influence of the interaction between learning model with ethnicity on science process skill. Although there is no interaction between the learning model and the ethnicity on the students' science process skills, it is necessary to disclose that there is an increase in the average skills of the science process of Malay and Dayak ethnic students in all treatments. The LSD notation also proves that the combination group of problem-based learning model through practicum supported by authentic assessment with Malay ethnic is significantly different with the problem-based learning model through practicum supported by authentic assessment with Dayak Ethnic, and also significantly different with the problem based learning of Malay and Dayak ethnic. Furthermore, the combined group of problembased learning models through practicum supported by authentic assessment with Malay ethnic shows a tendency of significant different with conventional learning of Malay and Dayak ethnic.

The average students' science-process skills on problem-based learning through practicum supported by authentic assessment are significantly different and higher from the average of students' science process skill on problem-based learning and conventional learning model. The high scores of students' science process skills after the learning with problem-based learning model through practicum supported by authentic assessment were due to the components of the learning model which support the development of science process skills, namely analyzing problems, practicing, and creating authentic tasks. The potential of problem-based learning is its ability to stimulate higher order thinking in problem-oriented situations, including awareness and skills in monitoring, organizing, and evaluating the process of learning or other skills (Goodnough and Cashion, 2003). Kanli et al. (2014) found that laboratory-based learning model with 7E cycle is more effective in improving students' science process skills. The improvement of such a psychomotor result is caused by the learning experience within an authentic assessment, which was experienced by students as a unity (collection of learning experience) within the student mind in the form of knowledge (cognitive), skills, values, and attitudes (Fajar, 2004).

\section{CONCLUSION}

Based on the results of data analysis and discussion, several conclusions can be drawn as follows:

1. The result of LSD test shows that there are significant differences between the three models, i.e. the problem-based learning model through a practicum supported by authentic assessment is significantly different with the problem-based learning model, and the problem-based learning model is significantly different with the conventional learning model.

2. Ethnicity has no effect on science process skills. It can be seen from the result of covariance analysis in which the F counted of ethnicity variable is 0.018 with the significance level of 0.89 which is bigger than the value of alpha 0 . 
3. There is no interaction effect of problem-based learning model, problem-based learning through a practicum supported by authentic assessment, and conventional learning with ethnicity toward students' science process skills.

\section{REFERENCES}

Akinbobola, A.O. \& Afolabi, F. (2010). Analysis of Science Process Skills in West African Senior Secondary School Certificate Physics Practical Examinations in Nigeria. American Eurasia Journal of Scientific Reseach, 5(4), 234-240.

Akınoğlu, O \& Tandoğan, R.Ö. (2007). The Effects of Problem-Based Active Learning in Science Education on Students'Academic Achievement, Attitude Concept Learning. Eurasia Journal of Mathematics, Science \& Technology Education, 3(1), 71-81.

Arends, R.I. (2008). Learning to Teach. New York: Mc Graw-Hill.

Ary, D., Jacobs, L.C. \& Razavieh, A. (1982). Pengantar Penelitian Dalam Pendidikan (Introduction to Research in Education). Surabaya: Penerbit Usaha Nasional.

Arvyaty \& Saputra, C. (2013). Pengaruh Model Pembelajaran terhadap Kemampuan Penalaran Proporsional Siswa Sekolah Menengah Pertama (The Influence of Learning Model on the Proportional Reasoning of Secondary School Students). Jurnal Pendidikan Matematika, 4(1), 62-73.

Aswandi. (2010). Membangun Peradaban Damai dalam Perspektif Melayu (Building a Civilization of Peace in Malay Perspective). Jurnal Pendidikan Sosiologi dan Humaniora, 1 (2), 8-11.

Azar, A. (2005). Pendidikan Multicultural: Cross Cultural Understanding untuk Demokrasi dan Keadilan.Yogyakarta: Pilar Media.

Dahar, A.M. (2011). Effect of the Availability and the Use of Science Laboratories on Academic Achievement of Students in Punjab (Pakistan). European Journal of Scientific Research, (online) 51(2), 193-202.

Duch B.J., Allen, D.E \& White, H.B. (2002). Problem Based Learning Preparing Students to Succeed in the $21^{\text {st }}$ Century, University of Delaware.

Duda, H.J. 2010. Pembelajaran Berbasis Praktikum dan asesmennya pada Konsep Sistem Peredaran Darah untuk Meningkatkan Kemampuan Berpikir Kritis dan Sikap Ilmiah Siswa SMA (Practical Based Learning and its Assessment on the Concepts of Circulatory Systems to Improve the Ability of Critical Thinking and Scientific Attitudes of High School Students). Tesis Magister, SPs UPI Bandung: tidak diterbitkan.

Duda, (2017). Metode Praktikum dan Asesmennya (Practical Methods and Assessments). Penerbit: STKIP Persada Khatulistiwa Sintang.

Fajar, A. 2004. Portofolio dalam Pembelajaran IPS (Portfolio in Social Studies). Penerbit: PT. Remaja Rosdakarya, Bandung. 
Frey, B.B., Schmitt, V.L., Allen, J.P. (2012). Defining Authentic Classroom Assessment. Journal Practical Assessment, Research \& Evaluation, 17 (02), 1-18.

Gabel, D.L. (1994). Handbook of Research on Science Teaching and Learning. New York: Mc Millan Publishing company.

Goodnough, K. \& Cashion, M. 2003. Fostering Inquary Through Problem Based Learning. The Science Teacher, 70(9): 21-25.

Halimatul \& Supriyanti. (2006). Penerapan Model Hipotesis Deduktif pada Praktikum Kinetika Enzim untuk Mengembangkan Keterampilan Berpikir Kritis Mahasiswa (Effect of Deductive Hypothesis Model on Enzyme Kinetics Practicum for Developing Student Critical Thinking Skills). Prosiding dalam Seminar Nasional di UPI Bandung.

Hart, D. (1994). Authentic Assessment a Handbook for Educators. Addison Weslay Alternative Publishing Group, California.

Hartono \& Rustaman, N.Y (2010). Penggunaan Blended Learning untuk Meningkatkan Keterampilan Proses Sains Mahasiswa (Use of Blended Learning to Improve Student Science Process Skills). Jurnal Penelitian Pendidikan IPA, 4 (1), 66-75.

Hmelo-Silver, C. E. (2004). Problem-Based Learning : What and How Do Students Learn? Educational Psychology Review, 16(3), 235-267.

Jeenthong, T., Ruenwongsa, P. \& Sriwattanarothai, N. (2014). Promoting Integrated Science Process Skills through Betta-Live Science Laboratory. Journal Social and Behavioral Sciences, 116, 3292-3296.

Jonassen, D.H. (1997). Instructional Design Models for Well-Structured and IllStructured Problem Solving Learning Outcomes. Educational Technology Research and Development, 45 (1), 65-94.

Kanli, U. \& Yagbasan, R. 2014. The Effects of a Laboratory Approaches on the Development of University Students' Science Process Skills and Conceptual Achievement. Journal Essays in Education Special Edition, University of South Carolina.

Kirschner, P. A., Sweller, J., \& Clark, R. E. (2006). Why Minimal Guidance During Instruction Does Not Work: an Analysis of The Failure of Constructivist, Discovery, Problem-Based, Experiential, and Inqury-Based Teaching. Educational Psychologist. 41(2), 75-86.

Kurniati, T. (2001). Pembelajaran Penedekatan Keterampilan Proses untuk Meningkatkan Keterampilan Berpikir Siswa (Learning Approach Process Skills to Improve Student Thinking Skills). Tesis tidak diterbitkan. Bandung: PPs UPI Bandung.

Kwan, C.Y. (2000). What is Problem-Based Learning (PBL). Journal Centre for Development of Teaching and Learning, 3 (3), 1-6.

Marhaeni, I.N. 2008. Asesmen Otentik dalam Pembelajaran Tematik di SD Kelas Awal (Authentic Assessment in Thematic Learning in Primary Class Elementary). Makalah 
Disampaikan pada Pelatihan Pembelajaran Tematik Bagi Guru SD di Kabupaten Karangasem.

McAlister, B. (2000). The Authenticity of Authentic Assessment: What the Research Says Or Doesn't Say. University of Wisconsin-Stout.

O’neil. J. (1992). Outting Performance Assessment to the Test. Educational Leadership, 49(8), 14-19.

Palm, T. (2008). Performance Assesment and Authentic Assesment: A Conceptual Analysis ot the Literature. Practical Assesment, Research, and Evaluation a Peer Reviewed Electronic Journal, 3 (4), 1-11.

Pantiwati, Y. (2012). Pengaruh Asesmen Biologi dalam Pembelajaran Think Pair Share Terhadap Kemampuan Kognitif Siswa (Effect of Biological Assessment on Think Pair Share Learning to Student Cognitive Ability). Jurnal Ilmu Pendidikan, 18 (02), 236243.

Pardhan, H. (2000). Science Activities and Ideas Experiencing. Science Process Skills. Canada: CMASTE University Alberta.

Purplenitadyah. 2012. Kebudayaan Dayak (Dayak culture). Makalah, http//suku dayak Kalimantan.

Rustaman, N. (2007). Strategi Belajar Mengajar Biologi (Biology Teaching Strategy). Malang. UM.

Santyasa, I.W. (2004). Model Problem Solving dan Reasoning Sebagai Alternative Pembelajaran Inovatif. Makalah disajikan dalam Konvensi Nasional Pendidikan Indonesia V. Bali: IKIP Negeri Singaraja.

Savery, J.R. (2006). Overview of Problem Based Learning: Definitons and Distinctions. Interdisciplinary Journal of Problem Based Learning, 1(3), 9-20.

Sungur, S., Tekkaya. C., Geban. O. (2006). Improving Achievement Through ProblemBased Learning. The Journal of Educational Research, 40 (4), 155-160.

Tan, O.S. (2003). Problem Based Learning Inovation, Using Problem to Power Learning in $21^{\text {st }}$ century. Cengage Learning Asia Pte Ltd. Singapore.

Trowbridge, LW. \& Bybee R.W. (1990). Becoming a Secondary School Science Teacher. Toronto: Merrill Publishing Company.

Villani, A. (1992). Conceptual Change in Science and Science Education. Science Education, 76(2), 223-237.

Wiggins, G. (1989). The Case for Authentic Assessment, Eric Digest Online.

Wulan, A.R. (2003). Permasalahan yang Dihadapi Dalam Pemberdayaan Praktikum Biologi di SMU dan Upaya Penanggulangannya. Tesis Medister pada SPs UPI Bandung: tidak diterbitkan. 
Wulan, A.R. (2007). Pembekalan Kemampuan Performance Assessment Kepada Calon Guru Biologi dalam Menilai Kemampuan Inkuiri (Procurement of Performance Assessment Capability To Biology Teacher Candidate in Assessing Inquiry Ability). Disertasi pada PPS UPI: tidak diterbitkan. 